\title{
Robust heterochiral strand displacement using leakless translators SUPPORTING INFORMATION
}

\author{
Tracy L. Mallette ${ }^{1}$, Milan N. Stojanovic ${ }^{2,3}$, Darko Stefanovic ${ }^{1,4}$, and Matthew R. Lakin ${ }^{1,4}$ \\ ${ }^{1}$ Center for Biomedical Engineering, University of New Mexico, Albuquerque, NM 87131, \\ USA \\ ${ }^{2}$ Division of Experimental Therapeutics, Department of Medicine, Columbia University \\ Medical Center, New York, NY 10032, USA \\ ${ }^{3}$ Departments of Biomedical Engineering and Systems Biology, Columbia University, New \\ York, NY 10027, USA \\ ${ }^{4}$ Department of Computer Science, University of New Mexico, Albuquerque, NM 87131, USA
}

May 17, 2020 


\section{Materials and Methods}

\section{DNA oligonucleotides}

Designs and oligonucleotide sequences were designed following the principles of leakless translator gate construction reported by Wang et al [1]. Additional sequence design was carried out using NUPACK [2-5] to produce minimally structured single strands and correctly folded gate complexes. Unmodified D-DNA oligonucleotides and all fluorophore- or quencher-modified oligonucleotides (both D-DNA and L-DNA) were purchased from IDT (Coralville, IA). Unmodified L-DNA oligonucleotides and hybrid DDNA / L-DNA oligonucleotides were purchased from ChemGenes (Wilmington, MA). All single strands for the inputs and gates were resuspended in TE buffer $(10 \mathrm{mM}$ Tris, $1 \mathrm{mM}$ EDTA) at a concentration of $1 \mu \mathrm{M}$ based on the synthesis yields as reported by the manufacturer. After the buffer was added, the DNA was vortexed, spun down, and stored in a $-20^{\circ} \mathrm{C}$ freezer until needed. Reporter strands were resuspended at $100 \mathrm{nM}$ using the same procedure.

\section{Other chemical reagents}

TE buffer and magnesium acetate were purchased from Millipore Sigma. TAE buffer, TBE buffer, Gibco DMEM, and Gibco Fetal Bovine Serum were purchased from Thermo Fisher Scientific. Ammonium persulfate and acrylamide/bis were purchased from BioRad. Urea, TEMED, EDTA, magnesium chloride, ammonium acetate, bromophenol blue solution, and glycerol were purchased from VWR.

\section{Oligonucleotide purification}

Single DNA strands from IDT and ChemGenes that were used as triggers or part of the gates were purified using a denaturing PAGE (dPAGE) gel. All dPAGE gel solutions were made with 8.3 M urea and in TBE buffer ( $89 \mathrm{mM}$ Tris base, $89 \mathrm{mM}$ Boric acid, $2 \mathrm{mM}$ EDTA). We used a separate stacking and resolving gels to improve resolution. The resolving gel was made with 15\% acrylamide:bis (19:1) solution and the stacking gel was made with 5\% acrylamide:bis (19:1) solution. Resolving gel was poured and cured for 30 minutes while topped with isopropyl alcohol to prevent drying of the interface. The stacking gel was poured at a height of twice the well fill and cured for one hour. After curing, the dPAGE gel was pre-run for 30 minutes in TBE upper running buffer with active heating to $55^{\circ} \mathrm{C}$ at $300 \mathrm{~V}$. Samples were loaded using 2:1 glycerol:bromophenol blue solution and then run for 2.5 hours. After running, the DNA band was cut from the gel using a razor blade and UV light to visualize. The DNA was then extracted from the gel using an elution buffer of $500 \mathrm{mM}$ ammoniuim acetate, $10 \mathrm{mM}$ magnesium acetate, and $2 \mathrm{mM}$ EDTA incubated at $37^{\circ} \mathrm{C}$ overnight followed by ethanol precipitation. We determined concentrations of the strands using a NanoDrop and the stated extinction coefficient as provided by the manufacturer.

\section{Gate complex purification}

After single strand purification, gates were prepared using equal stoichiometry of top and bottom strand in a TE buffer with $12.5 \mathrm{mM} \mathrm{Mg}^{2+}$ from an $\mathrm{MgCl}_{2}$ stock solution. Gates were annealed by raising the temperature to $95^{\circ} \mathrm{C}$ for five minutes and then slowly ramping down to $20^{\circ} \mathrm{C}$ over 1.5 hours. They were then purified using non-denaturing PAGE gels. The PAGE gel solutions were made in TAE buffer (40 $\mathrm{mM}$ Tris, $40 \mathrm{mM}$ acetic acid, $1 \mathrm{mM}$ EDTA) and $12.5 \mathrm{mM} \mathrm{Mg}^{2+}$ from an $\mathrm{MgCl}_{2}$ stock solution. The resolving gel was made with 12\% acrylamide:bis (19:1) solution and the stacking gel was made with

6\% acrylamide:bis (19:1) solution. The PAGE gel was poured similarly to the dPAGE gel with resolving and stacking gels. The PAGE gel run conditions were in TAE with $\mathrm{Mg}^{2+}$ buffer with active cooling to 
$25^{\circ} \mathrm{C}$ for 5 hours at $250 \mathrm{~V}$, with the buffer exchanged every 90 minutes. Samples were loaded using 2:1 glycerol:Bromophenol Blue solution. After running, the DNA was extracted from the gel using an elution buffer of TE buffer with $12.5 \mathrm{mM} \mathrm{Mg}^{2+}$ incubated at $30^{\circ} \mathrm{C}$ overnight. Extinction coefficients for gate complexes were calculated using the method of Tataurov et al [6]. Stock concentrations of complexes were calcualted using these extinction coefficients in conjunction with absorbance measurements taken on a Thermo Scientific NanoDrop 2000c.

\section{Reporter formation}

To avoid needing to quantify the fluorophore after running a gel, reporter strands were ordered from IDT purified. The reporter complex was prepared using a 10\% excess of quencher to reduce the chances of free fluorophore strands increasing background signal. The reporter complex was stored in TE buffer with $12.5 \mathrm{mM} \mathrm{Mg}^{2+}$ from an $\mathrm{MgCl}_{2}$ stock solution.

\section{Assays in buffer}

The initial strand displacement reaction assays were run in $\mathrm{TE} \mathrm{Mg}^{2+}$ buffer $(10 \mathrm{mM}$ Tris, $1 \mathrm{mM}$ EDTA, $12.5 \mathrm{mM} \mathrm{Mg}^{2+}$ ) with standard circuit component concentrations of $300 \mathrm{nM}$ and a reaction volume of $15 \mu \mathrm{L}$. All buffer experiments were run in triplicate at ambient temperature in a 384 well plate. Sealing tape was used to prevent evaporation effects during the long run times. Fluorescence monitoring of the reaction was done on a Biotek H1MG Synergy plate reader through a bottom read excitation wavelength of $497 \mathrm{~nm}$ and emission wavelength of $525 \mathrm{~nm}$. Kinetic data was recorded with readings taken once every minute.

\section{Assays in serum}

The serum assays were run similarly to the strand displacement assays in buffer. These experiments were run in $12.5 \mathrm{mM} \mathrm{Mg}^{2+}, 10 \%$ fetal bovine serum (FBS), and the remaining volume DMEM. (A physiological concentration of $\mathrm{Mg}^{2+}$ would be closer to $1 \mathrm{mM}$, however, we note that our strand displacement reactions should perform qualitatively similarly in physiological conditions given that previous work has demonstrated strand displacement reactions in living mammalian cells [7].) The initial reaction volume was $15 \mu \mathrm{L}$. Inputs were added by spiking in $16 \mu \mathrm{L}$ of $3 \mu \mathrm{M}$ trigger. The plate was incubated in the Biotek H1MG at $37^{\circ} \mathrm{C}$ and data readings were taken every minute for the first 30 minutes and every five minutes for the remainder of the incubation time to avoid photo-bleaching of the reporter. After the incubation period, trigger was spiked into the reaction wells and the plate was re-sealed. A 10 second lateral shake was done by the plate reader before reading the fluorescence every minute. Reactions were run in triplicate. Excitation and emission wavelengths were the same as for assays in buffer.

\section{Normalization of fluorescence data}

Data shown in Figure $1 \mathrm{f}$ was normalized to illustrate the linearity of activation, as follows. The negative control was taken as the average of the last 30 minutes of reporter only data. The positive control was taken as the average of the last 30 minutes of $1 \times$ input. The raw fluorescence readings were then normalized by linear interpolation between the appropriate chirality negative and positive controls.

Data shown in Figure S1 was normalized to illustrate relative signal strengths of the D>L, L $>$ D, and D $>$ D translators, as follows. $300 \mathrm{nM}$ of the appropriate ATTO488 reporter strand (that is, L-DNA or D-DNA) was prepared from purchased stock based on reported concentrations from IDT, as described above. Fluorescence of the single-stranded fluorescent oligonucleotide was measured over 12 hours and the readings from the last 60 minutes was averaged to use as a positive control. The raw fluorescence 
readings were then normalized by linear interpolation between the appropriate chirality negative and positive controls, as described above.

\section{Melt curve experiments}

The melt curves of the three T1 gates (from the $\mathrm{D}>\mathrm{L}, \mathrm{L}>\mathrm{D}$, and $\mathrm{D}>\mathrm{D}$ translators) were found by measuring absorbance at $260 \mathrm{~nm}$ (A260) over a range of temperatures. Complexes, prepared and purified as detailed above, were diluted to $3 \mu \mathrm{M}$ concentration for measuring. The samples were run in quartz cuvettes on an Agilent Technologies Cary 300 UV-Vis Spectrophotometer and attached temperature controller. The temperature started at $35^{\circ} \mathrm{C}$ and was increased at a rate of $1{ }^{\circ} \mathrm{C} \mathrm{min}^{-1}$ up to $90^{\circ} \mathrm{C}$. Absorbance measurements were taken every minute at a wavelength of $260 \mathrm{~nm}$. The curves were normalized by taking the mean of the five lowest readings as " 0 " and the mean of the five highest readouts as " 1 ". Then, the half-max point was calculated as the temperature at which the absorbance was halfway between the " 0 " and " 1 " normalized values.

\section{Nucleotide sequences}

Here, we use the following nucleotide sequence code: the D-DNA nucleotide $X$ is listed as $[\mathrm{dX}]$, and the L-DNA nucleotide $\mathrm{Y}$ is listed as [ldY]. We use [5ATTO488N] to represent a 5' ATTO 488 fluorophore modification and [3IABkFQ] to represent the corresponding 3' Iowa Black dark quencher modification. We write G-t and G-b for the "top" and "bottom" strands of gate complex G, respectively. We use the prefixes $\mathrm{L}>\mathrm{D}, \mathrm{D}>\mathrm{L}$, and $\mathrm{D}>\mathrm{D}$ to identify the chirality of the input and output signals from translator gates, and the prefixes $\mathrm{D}$ and $\mathrm{L}$ to identify the chirality of single strands. The sequences for all oligonucleotides used in this study are presented in Tables S1, S2, and S3. 


\begin{tabular}{|c|c|}
\hline Name & Sequence \\
\hline D_X & $\begin{array}{l}{[\mathrm{dC} C[\mathrm{dC}][\mathrm{dC}][\mathrm{dT}][\mathrm{dT}][\mathrm{dT}][\mathrm{dC} C[\mathrm{dT}][\mathrm{dC}][\mathrm{dA}][\mathrm{dT}][\mathrm{dA}][\mathrm{dA}][\mathrm{dT}][\mathrm{dC}][\mathrm{dT}][\mathrm{dC}][\mathrm{dA}][\mathrm{dC}]} \\
{[\mathrm{dA}][\mathrm{dC}][\mathrm{dT}][\mathrm{dT}][\mathrm{dC}][\mathrm{dT}][\mathrm{dC}][\mathrm{dC}][\mathrm{d} C][\mathrm{dA}][\mathrm{dA}]}\end{array}$ \\
\hline $\mathrm{D}>\mathrm{L} \_\mathrm{T} 1-\mathrm{t}$ & 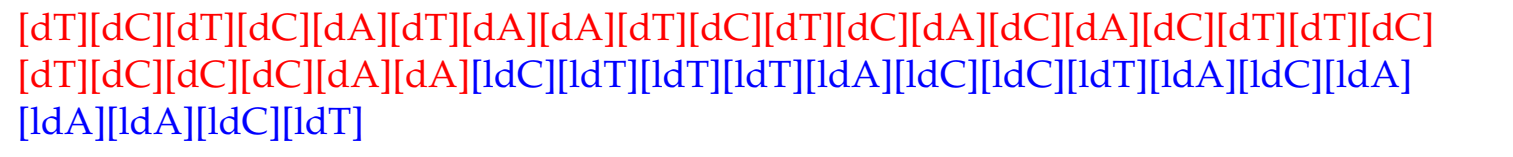 \\
\hline $\mathrm{D}>\mathrm{L} \_\mathrm{T} 1-\mathrm{b}$ & 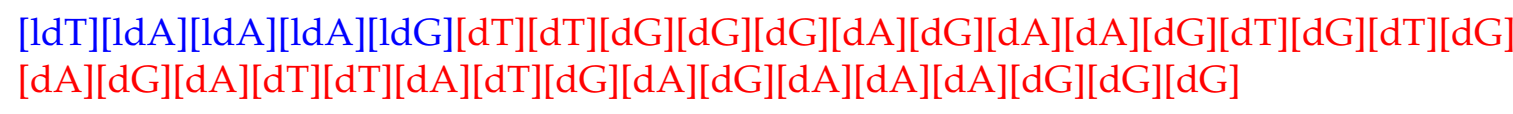 \\
\hline $\mathrm{D}>\mathrm{L} \_\mathrm{T} 2-\mathrm{t}$ & 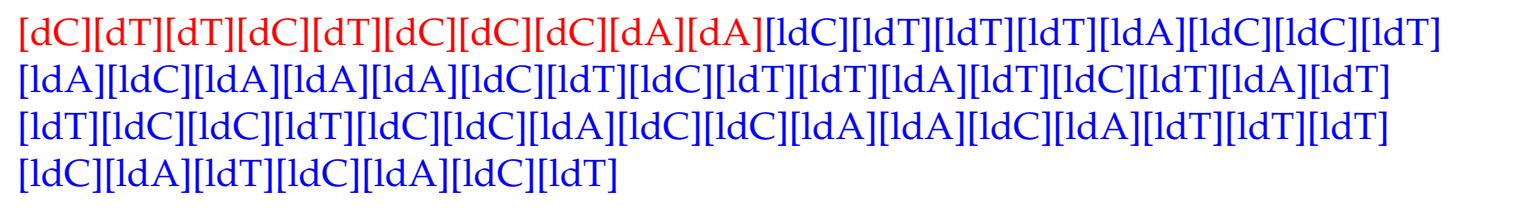 \\
\hline $\mathrm{D}>\mathrm{L} \_\mathrm{T} 2-\mathrm{b}$ & 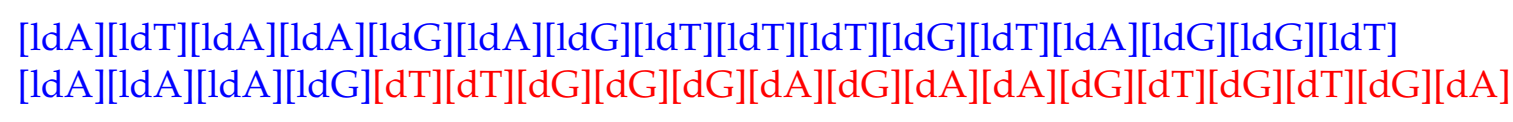 \\
\hline L_R-t & 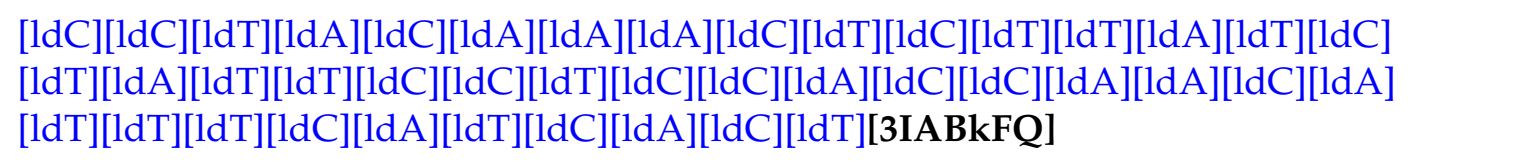 \\
\hline L_R-b & $\begin{array}{l}\text { [5ATTO488N][ldA][ldG][ldT][ldG][ldA][ldT][ldG][ldA][ldA][ldA][ldT][ldG][ldT][ldT] } \\
\text { [ldG][ldG][ldT][ldG][ldG][ldA][ldG][ldG][ldA][ldA][ldT][ldA][ldG][ldA][ldT][ldA] } \\
\text { [ldA][ldG][ldA][ldG][ldT][ldT][ldT][ldG][ldT][ldA][ldG][ldG][ldT][ldA][ldA][ldA] } \\
\text { [ldG] }\end{array}$ \\
\hline
\end{tabular}

Table S1: Nucleotide sequences for D>L heterochiral translator circuit. 


\begin{tabular}{|c|c|}
\hline Name & Sequence \\
\hline L_X & 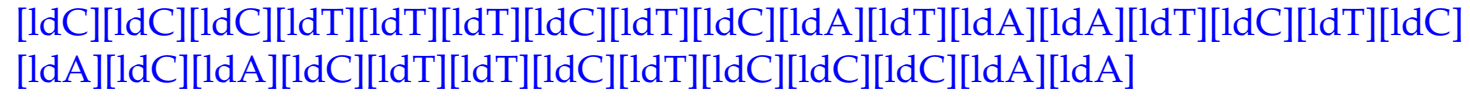 \\
\hline $\mathrm{L}>\mathrm{D} \_\mathrm{T} 1-\mathrm{t}$ & 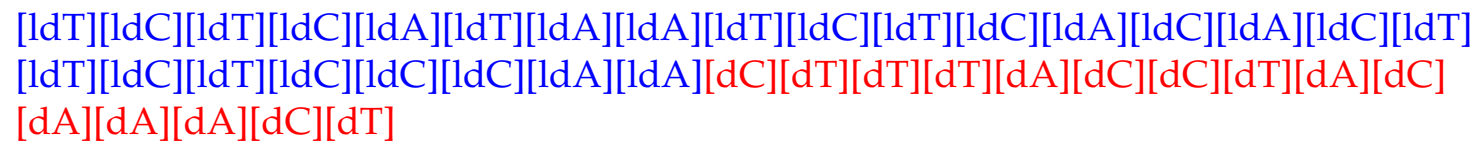 \\
\hline L>D_T1-b & $\begin{array}{l}\text { [dT][dA][dA][dA][dG][ldT][ldT][ldG][ldG][ldG][ldA][ldG][ldA][ldA][ldG][ldT][ldG] } \\
\text { [ldT][ldG][ldA][ldG][ldA][ldT][ldT][ldA][ldT][ldG][ldA][ldG][ldA][ldA][ldA][ldG] } \\
\text { [ldG][ldG] }\end{array}$ \\
\hline $\mathrm{L}>\mathrm{D} \_\mathrm{T} 2-\mathrm{t}$ & 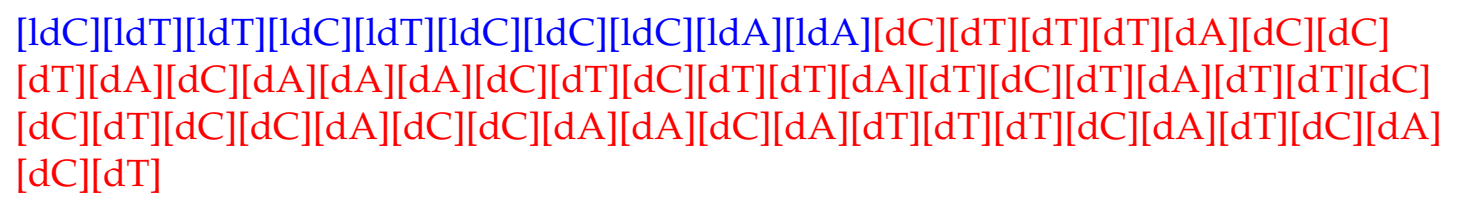 \\
\hline $\mathrm{L}>\mathrm{D} \_\mathrm{T} 2-\mathrm{b}$ & $\begin{array}{l}{[\mathrm{dA}][\mathrm{dT}][\mathrm{dA}][\mathrm{dA}][\mathrm{dG}][\mathrm{dA}][\mathrm{dG}][\mathrm{dT}][\mathrm{dT}][\mathrm{dT}][\mathrm{dG}][\mathrm{dT}][\mathrm{dA}][\mathrm{dG}][\mathrm{dG}][\mathrm{dT}][\mathrm{dA}][\mathrm{dA}][\mathrm{dA}]} \\
{[\mathrm{dG}][\mathrm{ldT}][\mathrm{d} T][1 \mathrm{~d} G][\mathrm{ld} G][\mathrm{d} G][\mathrm{ldA}][\mathrm{ldG}][\mathrm{ldA} A[\mathrm{ldA}][\mathrm{ldG}][\mathrm{ldT}][\mathrm{ld} G][\mathrm{ldT}][\mathrm{ld} G][\mathrm{ldA}]}\end{array}$ \\
\hline D_R-t & 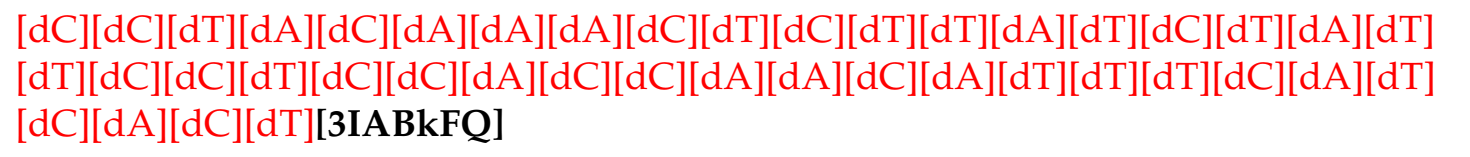 \\
\hline D_R-b & 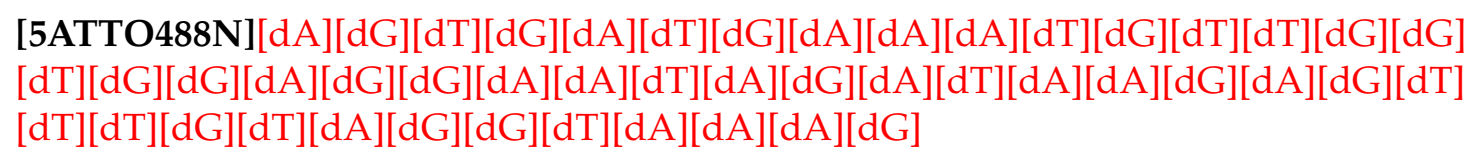 \\
\hline
\end{tabular}

Table S2: Nucleotide sequences for L $>$ D heterochiral translator circuit. 


\begin{tabular}{|c|c|}
\hline Name & Sequence \\
\hline D_X & $\begin{array}{l}{[\mathrm{dC}][\mathrm{dC}][\mathrm{dC}][\mathrm{dT}][\mathrm{dT}][\mathrm{dT}][\mathrm{dC}][\mathrm{dT}][\mathrm{dC}][\mathrm{dA}][\mathrm{dT}][\mathrm{dA}][\mathrm{dA}][\mathrm{dT}][\mathrm{dC}][\mathrm{dT}][\mathrm{dC}][\mathrm{dA}][\mathrm{dC}]} \\
{[\mathrm{dA}][\mathrm{dC}][\mathrm{dT}][\mathrm{dT}][\mathrm{dC}][\mathrm{dT}][\mathrm{dC}][\mathrm{dC}][\mathrm{dC}][\mathrm{dA}][\mathrm{dA}]}\end{array}$ \\
\hline $\mathrm{D}>\mathrm{D} \_\mathrm{T} 1-\mathrm{t}$ & 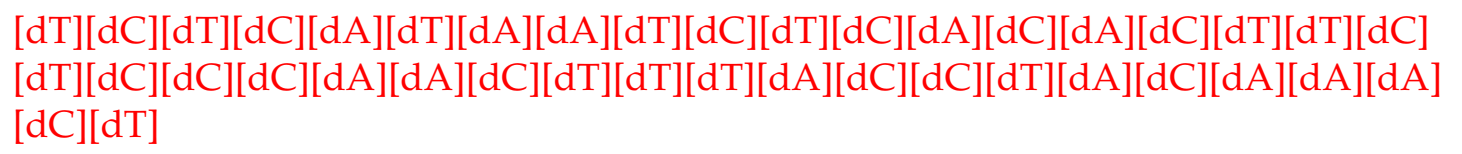 \\
\hline D>D_T1-b & $\begin{array}{l}{[\mathrm{dT}][\mathrm{dA}][\mathrm{dA}][\mathrm{dA}][\mathrm{dG}][\mathrm{dT}][\mathrm{dT}][\mathrm{dG}][\mathrm{dG}][\mathrm{dG}][\mathrm{dA}][\mathrm{dG}][\mathrm{dA}][\mathrm{dA}][\mathrm{dG}][\mathrm{dT}][\mathrm{dG}][\mathrm{dT}][\mathrm{dG}]} \\
{[\mathrm{dA}][\mathrm{dG}][\mathrm{dA}][\mathrm{dT}][\mathrm{dT}][\mathrm{dA}][\mathrm{dT}][\mathrm{dG}][\mathrm{dA}][\mathrm{dG}][\mathrm{dA}][\mathrm{dA}][\mathrm{dA}][\mathrm{dG}][\mathrm{dG}][\mathrm{dG}]}\end{array}$ \\
\hline $\mathrm{D}>\mathrm{D} \_\mathrm{T} 2-\mathrm{t}$ & $\begin{array}{l}{[\mathrm{dC}][\mathrm{dT}][\mathrm{dT}][\mathrm{dC}][\mathrm{dT}][\mathrm{dC}][\mathrm{dC}][\mathrm{dC}][\mathrm{dA}][\mathrm{dA}][\mathrm{dC}][\mathrm{dT}][\mathrm{dT}][\mathrm{dT}][\mathrm{dA}][\mathrm{dC}][\mathrm{dC}][\mathrm{dT}][\mathrm{dA}]} \\
{[\mathrm{dC}][\mathrm{dA}][\mathrm{dA}][\mathrm{dA}][\mathrm{dC}][\mathrm{dT}][\mathrm{dC}][\mathrm{dT}][\mathrm{dT}][\mathrm{dA}][\mathrm{dT}][\mathrm{dC}][\mathrm{dT}][\mathrm{dA}][\mathrm{dT}][\mathrm{dT}][\mathrm{dC}][\mathrm{dC}][\mathrm{dT}]} \\
{[\mathrm{dC}][\mathrm{d} C][\mathrm{dA}][\mathrm{dC}][\mathrm{dC}][\mathrm{dA}][\mathrm{dA}][\mathrm{dC}][\mathrm{dA}][\mathrm{dT}][\mathrm{dT}][\mathrm{dT}][\mathrm{dC}][\mathrm{dA}][\mathrm{dT}][\mathrm{dC}][\mathrm{dA}][\mathrm{dC}][\mathrm{dT}]}\end{array}$ \\
\hline $\mathrm{D}>\mathrm{D} \_\mathrm{T} 2-\mathrm{b}$ & $\begin{array}{l}{[\mathrm{dA}][\mathrm{dT}][\mathrm{dA}][\mathrm{dA}][\mathrm{dG}][\mathrm{dA}][\mathrm{dG}][\mathrm{dT}][\mathrm{dT}][\mathrm{dT}][\mathrm{dG}][\mathrm{dT}][\mathrm{dA}][\mathrm{dG}][\mathrm{dG}][\mathrm{dT}][\mathrm{dA}][\mathrm{dA}][\mathrm{dA}]} \\
{[\mathrm{dG}][\mathrm{dT}][\mathrm{dT}][\mathrm{dG}][\mathrm{dG}][\mathrm{dG}][\mathrm{dA}][\mathrm{dG}][\mathrm{dA}][\mathrm{dA}][\mathrm{dG}][\mathrm{dT}][\mathrm{dG}][\mathrm{dT}][\mathrm{dG}][\mathrm{dA}]}\end{array}$ \\
\hline D_R-t & $\begin{array}{l}{[\mathrm{dC}][\mathrm{dC}][\mathrm{dT}][\mathrm{dA}][\mathrm{dC}][\mathrm{dA}][\mathrm{dA}][\mathrm{dA}][\mathrm{dC}][\mathrm{dT}][\mathrm{dC}][\mathrm{dT}][\mathrm{dT}][\mathrm{dA}][\mathrm{dT}][\mathrm{dC}][\mathrm{dT}][\mathrm{dA}][\mathrm{dT}]} \\
{[\mathrm{dT}][\mathrm{dC}][\mathrm{dC}][\mathrm{dT}][\mathrm{dC}][\mathrm{dC}][\mathrm{dA}][\mathrm{dC}][\mathrm{dC}][\mathrm{dA}][\mathrm{dA}][\mathrm{dC}][\mathrm{dA}][\mathrm{dT}][\mathrm{dT}][\mathrm{dT}][\mathrm{dC}][\mathrm{dA}][\mathrm{dT}]} \\
{[\mathrm{dC}][\mathrm{dA}][\mathrm{dC}][\mathrm{dT}][\mathbf{3 I A B k F Q}]}\end{array}$ \\
\hline D_R-b & $\begin{array}{l}\text { [5ATTO488N][dA][dG][dT][dG][dA][dT][dG][dA][dA][dA][dT][dG][dT][dT][dG][dG] } \\
{[\mathrm{dT}][\mathrm{dG}][\mathrm{dG}][\mathrm{dA}][\mathrm{dG}][\mathrm{dG}][\mathrm{dA}][\mathrm{dA}][\mathrm{dT}][\mathrm{dA}][\mathrm{dG}][\mathrm{dA}][\mathrm{dT}][\mathrm{dA}][\mathrm{dA}][\mathrm{dG}][\mathrm{dA}][\mathrm{dG}][\mathrm{dT}]} \\
{[\mathrm{dT}][\mathrm{dT}][\mathrm{dG}][\mathrm{dT}][\mathrm{dA}][\mathrm{dG}][\mathrm{dG}][\mathrm{dT}][\mathrm{dA}][\mathrm{dA}][\mathrm{dA}][\mathrm{dG}]}\end{array}$ \\
\hline
\end{tabular}

Table S3: Nucleotide sequences for D>D control translator circuit. 


\section{Supplementary Figures}

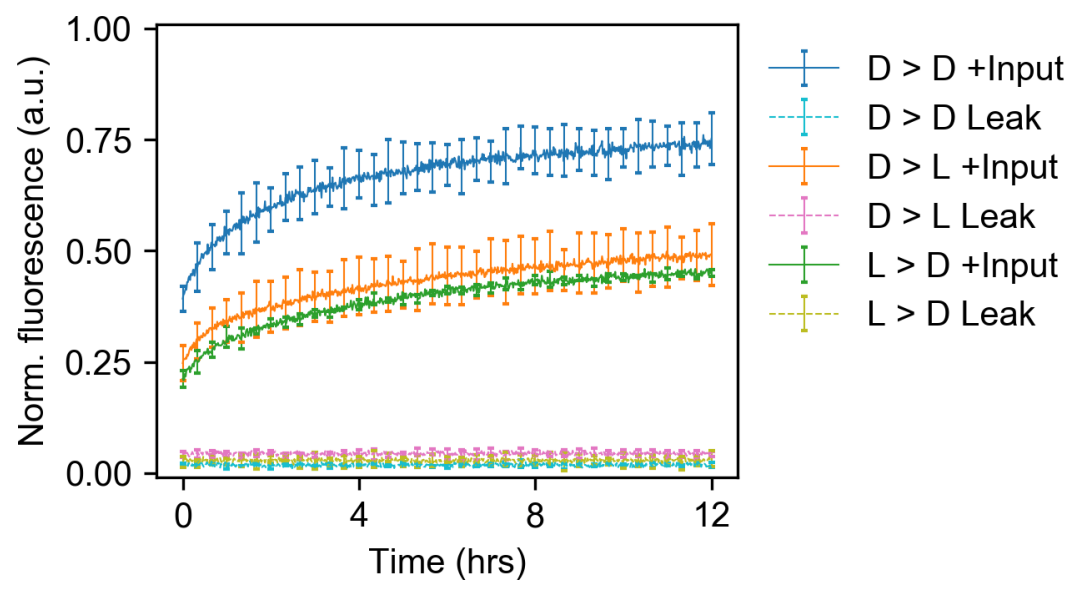

Figure S1: Normalized fluorescence timecourses of signal translation in heterochiral translators from D-DNA input to L-DNA output (D>L) and from L-DNA input to D-DNA output ( $>$ D). A pure D-DNA translator $(\mathrm{D}>\mathrm{D})$ is included as a control. Reporter and gates are at concentrations of $300 \mathrm{nM}$ and $1 \times$ input $(300 \mathrm{nM})$ is supplied. Background level of signal with $0 \times$ input ("leak") is indicated with dashed lines. Plot shows mean and standard deviation of three replicates. This data was normalized to a fluorescent reporter strand of the corresponding chirality, as outlined in the "Normalization of fluorescence data" subsection of "Materials and Methods". 

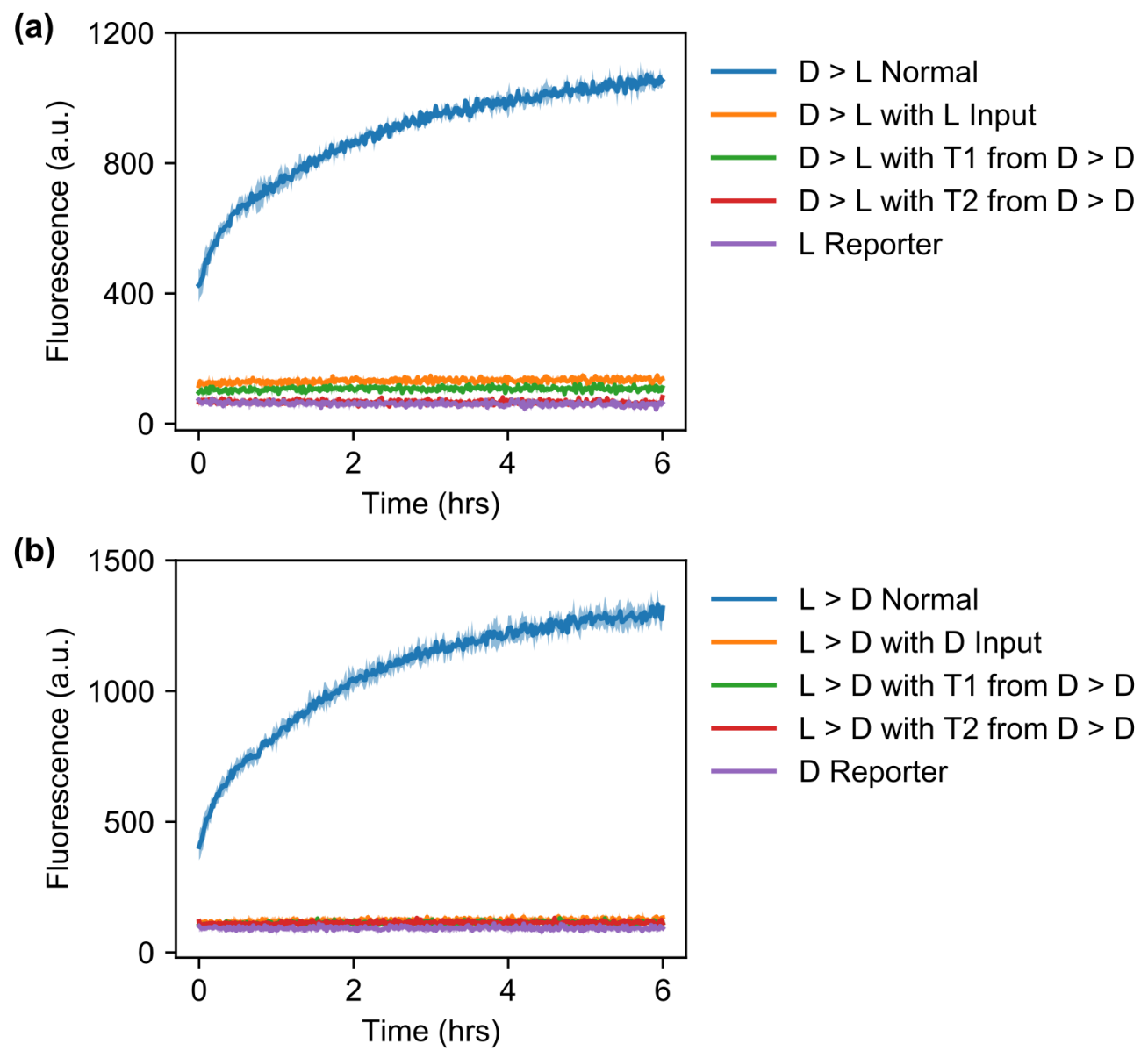

Figure S2: Kinetic timecourses of chiral specificity controls for leakless heterochiral translators. (a) Demonstration of chiral specificity of components in the D $>$ L heterochiral translator. Mirroring the chirality of the input or replacing one of the translator gates (T1 or T2) with the homochiral version from the $\mathrm{D}>\mathrm{D}$ translator suffices to reduce circuit output to background levels, thereby demonstrating chiral specificity of our translator architecture. (b) Similar demonstration of chiral specificity of components in the $\mathrm{L}>\mathrm{D}$ heterochiral translator. Each plot shows mean and standard deviation of three replicates. Concentrations of all gates, $1 \times$ input, and reporter are $300 \mathrm{nM}$. 


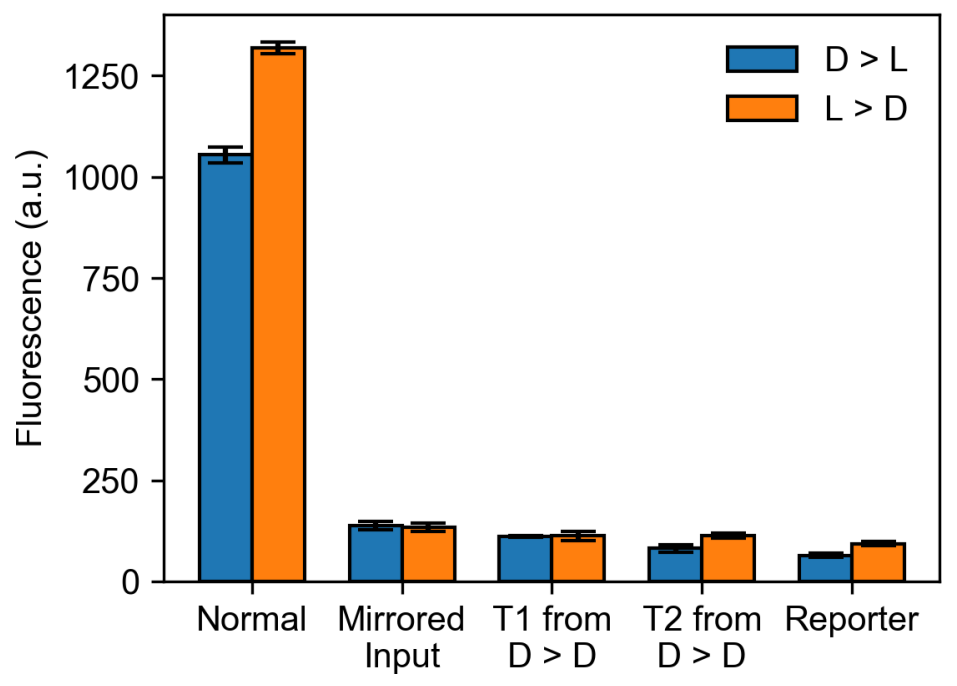

Figure S3: Endpoint comparision of chirality controls for $\mathrm{D}>\mathrm{L}$ and $\mathrm{L}>\mathrm{D}$ leakless heterochiral translators. Endpoint values from Figure S2 are plotted for comparison. In all cases, mirroring the chirality of the input or replacing one of the translator gates (T1 or T2) with the homochiral version from the D>D translator suffices to reduce circuit output to background levels, thereby demonstrating chirality specificity of our translator architecture. Plot shows mean and standard deviation of three replicates. Concentrations of all gates, $1 \times$ input, and reporter are $300 \mathrm{nM}$. 


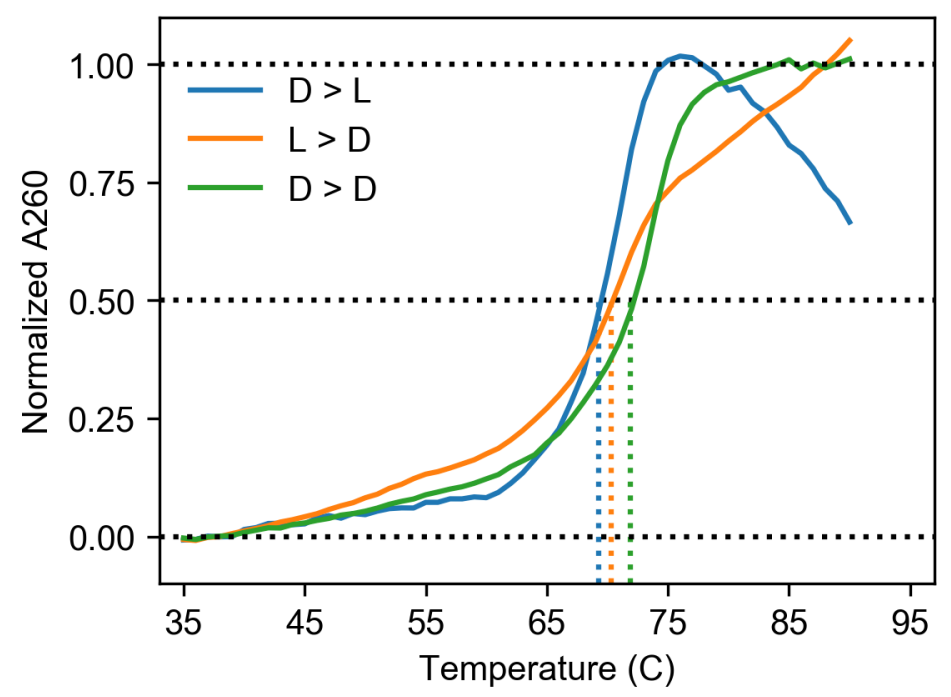

Figure S4: UV-vis experiments to measure melt curves for heterochiral and homochiral translators. The calculated half-max values are shown by vertical lines and are as follows: $\mathrm{D}>\mathrm{L}=69.27^{\circ} \mathrm{C}, \mathrm{L}>\mathrm{D}=70.31^{\circ} \mathrm{C}$, $\mathrm{D}>\mathrm{D}=71.91^{\circ} \mathrm{C}$. This suggests a small lowering of the melting temperature caused by the presence of a chiral crossover in the molecule, although the difference is not signficant. Samples were prepared at $3 \mu \mathrm{M}$, and A260 readings were normalized, as outlined above. The drop in the absorbance signal at the high end of the $\mathrm{D}>\mathrm{L}$ trace could be caused by evaporation of the sample during heating. 
(a)
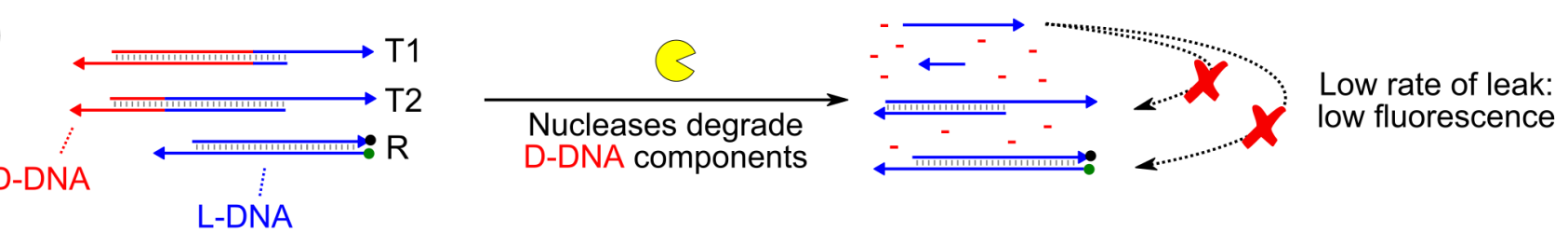

(b)
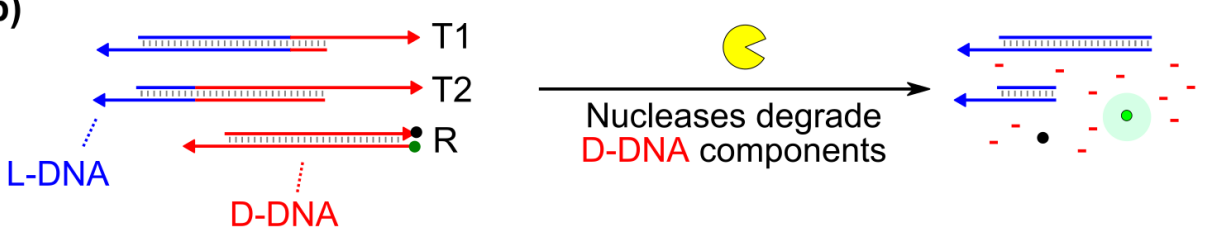

High rate of leak / direct degradation of reporter: high fluorescence

(c)
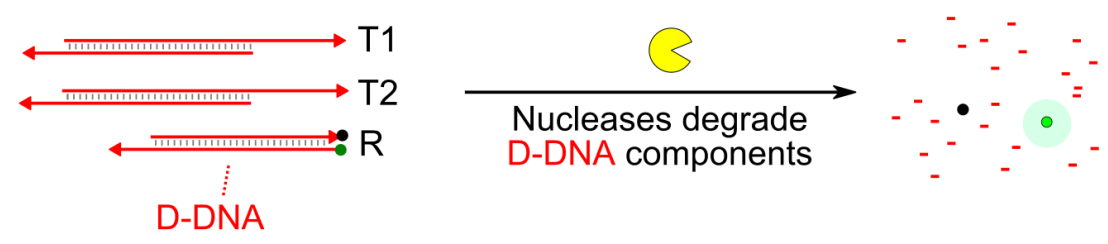

High rate of leak / direct degradation of reporter: high fluorescence

Figure S5: Cartoons illustrating the effects of nuclease degradation on heterochiral leakless translators when incubated in serum. (a) In a D>L heterochiral translator system, the upstream (input-sensing) domains may be degraded by nucleases. The reporter gate remains intact and the remains of the other gates can only activate the reporter via blunt end strand displacement reactions which have a low rate constant. Hence the observed level of fluorescence should be low. (b) In an L $>$ D heterochiral translator systen, the downstream (output-signaling) domains and the reporter itself may be degraded by nucleases. Thus, degraded T1 and T2 gates may more readily activate the reporter, and the reporter itself may be directly degraded. Hence the observed level of fluorescence should be high. (c) In a D $>D$ homochiral translator system (control), both the upstream (input-sensing) and downstream (output-signaling) domains and the reporter itself may be degraded by nucleases. Thus, degraded T1 and T2 gates may more readily activate the reporter, and the reporter itself may be directly degraded. Hence the observed level of fluorescence should be high. 


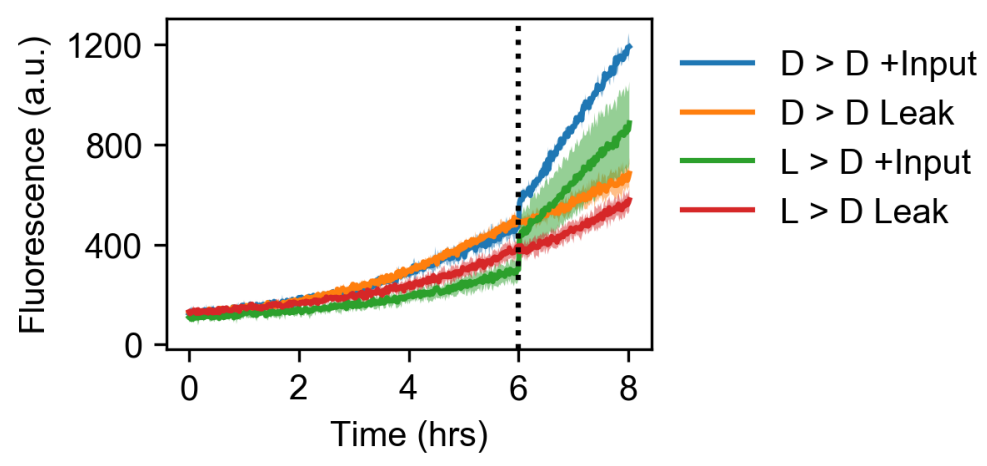

Figure S6: $10 \%$ serum incubation experiment comparing $\mathrm{D}>\mathrm{D}$ to $\mathrm{L}>\mathrm{D}$ translators. The translators in the "+Input" condition were activated after 6 hours (dotted vertical line) by the addition of $10 \times$ input, while the translators in the "Leak" condition were not activated. The L $>$ D system follows a similar trajectory to the $\mathrm{D}>\mathrm{D}$ system, thereby confirming the key leak mechanism of nuclease-driven degradation of the DDNA circuit components. This result stands in contrast to that from Figure $2 \mathrm{~b}$ in the main text, where the D>L translator exhibits significantly less leak because the circuit design mitigates against leak from the downstream L-DNA components, even when the upstream D-DNA components have been degraded. Plot shows mean and standard deviation of three replicates. Concentrations of all gates, $1 \times$ input, and reporter are $300 \mathrm{nM}$. 


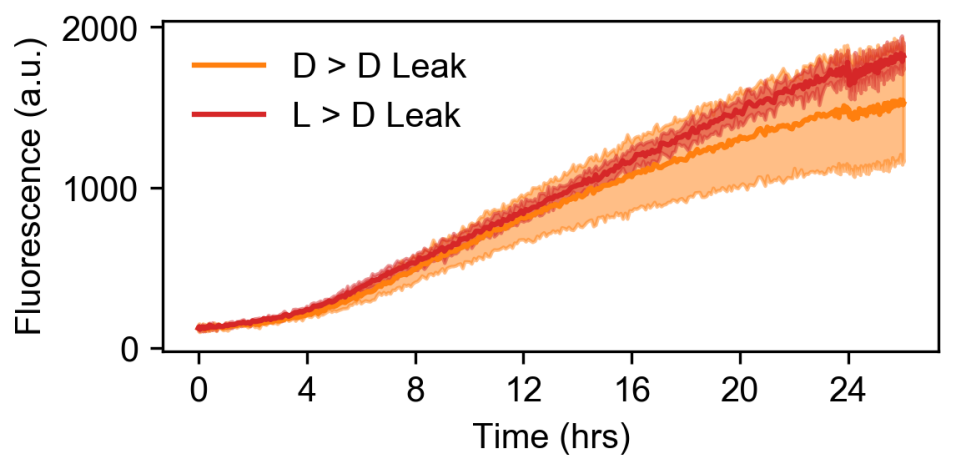

Figure S7: 10\% serum incubation experiment comparing leak from D>D and L $>$ D translators over 26 hours. The L $>$ D system follows a similar trajectory to the D $>$ D system, thereby confirming the key leak mechanism of nuclease-driven degradation of the D-DNA circuit components. This result stands in contrast to that from Figure $2 \mathrm{c}$ in the main text, where the $\mathrm{D}>\mathrm{L}$ translator exhibits significantly less leak because the circuit design mitigates against leak from the downstream L-DNA components, even when the upstream D-DNA components have been degraded. Plot shows mean and standard deviation of three replicates. Concentrations of all gates, $1 \times$ input, and reporter are $300 \mathrm{nM}$. 


\section{References}

[1] Wang B, Thachuk C, Ellington AD, Winfree E, Soloveichik D. Effective design principles for leakless strand displacement systems. Proc Natl Acad Sci U S A. 2018;115(52):E12182-E12191.

[2] Wolfe BR, Pierce NA. Sequence Design for a Test Tube of Interacting Nucleic Acid Strands. ACS Synth Biol. 2015;4(10):1086-1100.

[3] Wolfe BR, Porubsky NJ, Zadeh JN, Dirks RM, Pierce NA. Constrained Multistate Sequence Design for Nucleic Acid Reaction Pathway Engineering. J Am Chem Soc. 2017;139(8):3134-3144.

[4] Zadeh JN, Steenberg CD, Bois JS, Wolfe BR, Pierce MB, Khan AR, et al. NUPACK: analysis and design of nucleic acid systems. J Comput Chem. 2011;32(1):170-173.

[5] Zadeh JN, Wolfe BR, Pierce NA. Nucleic acid sequence design via efficient ensemble defect optimization. J Comput Chem. 2011;32:439-452.

[6] Tataurov AV, You Y, Owczarzy R. Predicting ultraviolet spectrum of single stranded and double stranded deoxyribonucleic acids. Biophys Chem. 2008;133(1-3):66-70.

[7] Groves B, Chen YJ, Zurla C, Pochekailov S, Kirschman JL, Santangelo PJ, et al. Computing in mammalian cells with nucleic acid strand exchange. Nat Nanotechnol. 2016;11:287-294. 